\title{
GIS-based Assessment of Groundwater Quality for Drinking and Irrigation by Water Quality Index
}

\author{
Arvind Gauns $^{1 *}$, M. Nagarajan ${ }^{1}$, R. Lalitha ${ }^{1}$ and M. Baskar ${ }^{2}$ \\ ${ }^{I}$ Department of Soil and Water Conservation Engineering, AEC \& RI Kumulur, TNAU, Trichy \\ ${ }^{2}$ Department of Soil Science and Agricultural Chemistry, IOA, Kumulur, TNAU, Trichy, India \\ *Corresponding author
}

\begin{tabular}{|l|}
\hline Ke y w o r d s \\
Groundwater \\
quality assessment, \\
Water quality index, \\
soluble Sodium \\
percentage, \\
Nemerows \\
Pollution Index \\
\hline Article Info \\
\hline Accepted: \\
15 February 2020 \\
Available Online: \\
10 March 2020 \\
\hline
\end{tabular}

A B S T R A C T

Groundwater is one of the crucial natural resources which meets the requirement of drinking as well as for irrigation. Increasing population, erratic distribution of rainfall and their rising demand for water in domestic and irrigation is fulfilled by groundwater resources. Hence, a geo-spatial study was conducted for groundwater sampling for water quality assessment to determine the suitability of water for drinking and irrigation purpose. For this study, five villages around AEC \& RI, Kumulur, Trichy, Tamil Nadu were selected as a study area with an aerial extent of $45.1 \mathrm{~km}^{2}$. For the assessment of groundwater quality, samples from 53 locations were collected from sources like open well, bore well and hand pump. The parameters viz. $\mathrm{pH}$, electrical conductivity, Anions (Chlorides, Carbonates, Bi-carbonates, Sulphates) and Cations (Calcium, Magnesium, Sodium, Potassium, Boron) were estimated using the standard analytical procedure. The different physico-chemical data of above analysis were used for the computation of three Water Quality Index (WQI) for drinking (WQI1 \& WQI2) and irrigation (WQI3) needs. The WQI variability thematic maps were generated in ArcGIS software using spatial interpolation technique, which provides a detailed overview of water quality status across the study area. The WQI1 and WQI2 show that water quality of the study area is far lower than the permissible limits which conclude the suitability of water for drinking. In WQI3, $96 \%$ samples fall under the permissible category and $4 \%$ samples i.e. $0.44 \mathrm{~km}^{2}$ area, fall under the very poor and unsuitable category, which needs treatment before usage for irrigation.

\section{Introduction}

Groundwater is one of the crucial natural resources which meets the requirement of drinking as well irrigation. Human activities on surface and subsurface are influencing the quality of the groundwater. Increasing population, erratic distribution of rainfall and their rising demand for water in domestic and irrigation is fulfilled by groundwater resources, as the water infiltrates through the different soil strata, it gets filtrated (Sureshkumar et al., 2018). Use of poor quality of water not just affects the growth of the crop, but there are many adverse effects affecting the physical condition of the soil, crop health and yield. Quality of the water used for irrigation is important to determine 
the success of the crops with different water requirements (Talukder et al., 1998). Hence it's necessary to understand the hydrogeochemical nature of the groundwater in regards to irrigation, which can contribute ineffective management of the crop and avoid impact on crop growth and its production (Reddy, 2013).

Water Quality Index (WQI) is a widely used tool in the evaluation of water quality. It summarizes different water quality parameters in a single number, which can be easily interpreted and acts as a key in forming a decision about water quality for estimating the water quality index, various chemical properties of groundwater were found out and following indices, i.e. Water Quality Index (WQI1), Neme rows Pollution Index (WQI2) and Soluble Sodium Percentage (WQI3) were used as suggested by Rawat\& Singh (2018).

In India, the salinity hazards is extensively irrigation related problem in semi-arid regions. In addition, demand of different crops needs different irrigation water qualities. Hence, testing the irrigation water, prior to use is necessary for contributing towards effective management of water and optimum utilization of the groundwater resources (Reddy, 2013). The study was undertaken with an objective to evaluate the groundwater quality from different groundwater sources and find its suitability for drinking and irrigation. Further based on the quality, a database can be established for planning future water resources development strategies.

\section{Materials and Methods}

\section{Study area}

For assessment of groundwater quality, 53 samples were collected across 5 villages of Kumulur watershed namely Kumulur,
Tachankurunchi, Pudurutamanur, Pandaravadai and Poovalur. The area falls in Lalgudi and Pulambadi block of Tiruchirapalli district with anwerial extent of 45.1 sq. $\mathrm{km}$. The average annual rainfall of this region is $881.412 \mathrm{~mm}$ (Vaidheki and Arulanandu, 2017). The water sampling was done in the month of September 2019. For sample collection, the methodology explained by Mani et al., (2007) was adopted. The groundwater samples were collected in a plastic PET bottle thoroughly cleaned and rinsed 3 to 4 times with the water to be tested.

The tube well or hand pump was run for about 15 to 20 minute to drain out the water retained in the pipe. The bottle was then washed repeatedly with the water before taking about $1000 \mathrm{~mL}$ of sample. From the open well, the sample was drawn either during irrigation, just before the water drops in the channel or by drawing it with the help of a bucket or any clean container using a rope. The water surface should be disturbed a little to remove any floating material before the sample collection. On a piece of paper of suitable size, write the name, address, sample number, identification mark etc. was written and pasted firmly on the bottle. The coordinates of the sampling sources in the study area were obtained from the Trimble Juno SD Handheld GPS device. Samples were analyzed for different parameters such as $\mathrm{pH}$, electrical conductivity, Anions (Chlorides $\left(\mathrm{Cl}^{-}\right)$, Carbonates $\left(\mathrm{CO}_{3}{ }^{2-}\right)$, Bi-carbonates $\left(\mathrm{HCO}_{3}{ }^{-}\right)$, Sulphates $\left.\left(\mathrm{SO}_{4}{ }^{2-}\right)\right)$ and Cations (Calcium $\left(\mathrm{Ca}^{2+}\right)$, Magnesium $\left(\mathrm{Mg}^{2+}\right)$, Sodium $\left(\mathrm{Na}^{+}\right)$, Potassium $\left(\mathrm{K}^{+}\right)$, Boron $\left.\left(\mathrm{B}^{3 \pm}\right)\right)$ using the methods given below (Table 1).

\section{Soil}

The major soil types encountered in the study area are clayey, red sandy to loamy soils and alluvial soils (Suresh, 2008). 


\section{Water quality index}

The water quality index also called weighted arithmetic index method was used for the calculation of WQI. Further, the quality rating or sub-index (Qn) was calculated using the following equations.

$\mathrm{Q}_{\mathrm{n}}=100 *\left[\frac{\left(\mathrm{V}_{\mathrm{n}}-\mathrm{v}_{\mathrm{i}}\right)}{\left(\mathrm{V}_{\mathrm{s}}-\mathrm{V}_{\mathrm{i}}\right)}\right]$

Where

Qn = Quality rating for the $n^{\text {th }}$ water quality parameter;

$\mathrm{V}_{\mathrm{n}}=$ Actual value of $\mathrm{n}^{\text {th }}$ parameter;

$\mathrm{v}_{\mathrm{i}}=$ Ideal value of this parameter;

$\mathrm{V}_{\mathrm{s}}=$ Standard permissible value of the $\mathrm{nth}$ parameter.

[Note: Consider $\mathrm{v}_{\mathrm{i}}=0$ for all except $\mathrm{pH}$ where $\mathrm{v}_{\mathrm{i}}=7$ for $\left.\mathrm{pH}\right]$.

The unit weight value is the reciprocal of the recommended standard value $(\mathrm{Vn})$, to the corresponding parameter.

$\mathrm{W}_{\mathrm{n}}=\frac{\mathrm{K}}{\mathrm{V}_{\mathrm{s}}}$

$\mathrm{K}=\frac{1}{\sum_{n=1}^{\mathrm{n}}\left(\frac{1}{\mathrm{~W}_{\mathrm{s}}}\right)}$

$\mathrm{W}_{\mathrm{n}}=$ Unit weight for the nth parameters;

$\mathrm{K}=$ constant for proportionality;

$\mathrm{Vs}=$ standard value for the $\mathrm{n}^{\text {th }}$ parameters.

The method of classifying the water quality is based on overall water quality index (WQI), which are calculated by aggregating the quality rating Qn linearly as expressed as follows:

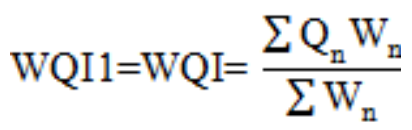

From the obtained values of WQI, the classification of the groundwater sample will be done as excellent, good, permissible very poor and unsuitable (Table 3 ).

\section{Nemerows Pollution Index (NPI or WQI2)}

NPI was defined for the purpose of classification using an index for expression of pollution for regional analysis of water quality. This index also considers for the effect of individual pollutant and it is used to evaluate the total damage caused due to pollution. It is an overall measure of pollutant considering the overall effect of multiple items of pollutants for a specific use. The index value takes relative particulates for the development of an index for any specific purpose i.e. drinking and irrigation (Nemerow, 1970). The WQI2 can be estimated using the expression:

$\mathrm{PI}_{\mathrm{n}}=\frac{\mathrm{V}_{\mathrm{n}}}{\mathrm{V}_{\mathrm{s}}}$

\section{$\mathrm{WQI} 2=\mathrm{NPI}=\Sigma \mathrm{PI}$}

where: $\mathrm{Vn}=$ Actual value of nth parameter; $\mathrm{Vs}=$ Standard permissible value of the $\mathrm{n}^{\text {th }}$ parameter.

\section{Soluble Sodium Percentage (SSP or WQI3)}

Sodium percentage plays an important role in analyzing sodium hazard, as a higher percentage in irrigation water can hamper the plant growth and reduce soil permeability. Sodium combines with carbonate to form sodium carbonate leading to the formation of alkali soil whereas with chlorides, resulting in the formation of saline soils. Both cases don't favour a suitable environment for plant growth (Rawat and Singh, 2018).

Wilcox (1955) devised a method to estimate the quality of irrigation in terms of sodium percentage. The sodium percentage can be 
calculated by using the following formula:

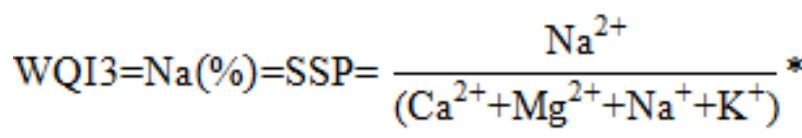

The WQI1, WQI2 and WQI3 were estimated based on the above parameter obtained andwas categorized for its suitability for drinking and irrigation. Based on the ratings given in Table 2, classification was done in five categories.

\section{Thematic maps}

Based on the calculated indices and parameters, thematic maps of the study area were generated using interpolation tool IDW (Inverse Distance Weightage) interpolation tool in GIS environment. ESRI's ArcGIS 10.3 software was used for generating the maps.

\section{Results and Discussion}

The study of the groundwater quality holds a vital significance in understanding the geoenvironmental implications, which may be attributed to the presence of different types of aquifer and anthropogenic activities (Reddy, 2013). The physico-chemical properties of the groundwater samples were estimated using the standard methods listed in Table 1 and the results obtained are tabulated below in Table 3. The standard permissible limit of the parameter is listed in Table 4. Based on the above parameters, for all 53 location coordinates were obtained and interpolated to form different water quality indices based thematic maps obtained using IDW tool in ArcGIS.

Based on the standard permissible limit by WHO (WHO 2006), classification of the water quality parameter was done. The summary of the samples falling under the permissible limit and the samples over the permissible limit are tabulated in Table 3. From the graphs, $3 \mathrm{pH}$ samples, 4 EC samples, 3 TDS samples, $13 \mathrm{Cl}^{-}$samples, 10 $\mathrm{Ca}^{2+}$ samples, $6 \mathrm{Mg}^{2+}$ samples, $9 \mathrm{Na}^{+}$samples and $5 \mathrm{~K}^{+}$samples cross the permissible limit. ${ }^{*} 100$ The $\mathrm{CO}_{3}{ }^{2-}$ are absent in the study area. All the samples of $\mathrm{HCO}_{3}{ }^{-}, \mathrm{B}^{3+}$ and $\mathrm{SO}_{4}{ }^{2-}$ fall under the permissible limits.

\section{Water Quality Index}

The water quality parameter was estimated using the above equations. It is clear from the readings that, multiple parameters influence water quality more than the individual parameter. The classification of the entire area was done with reference to the water quality ratings in Table 2 for WQI1. With reference to the permissible limits, proportionality constant (K) and the unit weight (Wn) (Table 4).

As per WQI1 ratings, 5\% samples comes under permissible quality, $74 \%$ samples comes under good water quality and $21 \%$ samples come under excellent water quality. Based on the coordinates of the location and quality parameters on the spatial data were interpolated using IDW tool in ArcGIS. The interpolation of WQI1 across the study area is shown in Fig. XVII.

\section{Nemerows Pollution Index}

For the 53 samples, WQI2 was obtained for the given water quality parameters. It also considers the impact of multiple parameters influencing the water quality. $\mathrm{PI}_{n}$ for individual parameters and NPI was calculated to obtain WQI2. Based on the water quality rating given in Table 2, the classification of water quality was done in 5 categories.

As per the WQI2 ratings, $11 \%$ samples comes under good water quality and $89 \%$ samples come under excellent water quality. Based on the values obtained, WQI2 was interpolated for the entire study area to generate water quality index map (Fig. XVIII) in ArcGIS. 
Table.1 Methodologies used for estimation of water quality parameter

\begin{tabular}{|l|c|l|}
\hline \multicolumn{1}{|c|}{ Parameter } & Methodology & \multicolumn{1}{c|}{ Reference } \\
\hline pH & pH meter & \\
\hline Electrical Conductivity & EC meter & \\
\hline Total Dissolved Solids & TDS meter & \\
\hline Sodium, Potassium & Flame Photometer & APHA (1998) \\
\hline Calcium, Magnesium & EDTA Titration & APHA (1998) \\
\hline Carbonate, bi-carbonate & Acid-base Titration & Mani et al. (2007) \\
\hline Chloride & AgNO Titration & APHA (1998) \\
\hline Sulphate & Spectrophotometer & APHA (1998) \\
\hline Boron & Spectrophotometer & Mani et al. (2007) \\
\hline
\end{tabular}

Table.2 Water quality ratings for WQI1 (WQI), WQI2 (NPI) and WQI3 (SSP)

\begin{tabular}{|c|c|c|c|}
\hline WQI1 & WQI2 & WQI3 & Category \\
\hline$<\mathbf{2 5}$ & $<10$ & $<40$ & Excellent \\
\hline $\mathbf{2 5}-\mathbf{5 0}$ & $10-20$ & $40-70$ & Good \\
\hline $\mathbf{5 0}-\mathbf{7 5}$ & $20-30$ & $70-80$ & Permissible \\
\hline $\mathbf{7 5}-\mathbf{1 0 0}$ & $30-40$ & $80-90$ & Very Poor \\
\hline$>\mathbf{1 0 0}$ & $>40$ & $>90$ & Unsuitable \\
\hline
\end{tabular}

(Rawat and Singh, 2018)

Table.3 Summary of parameters based on permissible limits prescribed by WHO (2006)

\begin{tabular}{|c|c|c|c|c|}
\hline Parameter & $\begin{array}{c}\text { Permissible limit } \\
\text { of a parameter for } \\
\text { drinking (WHO, } \\
2006)\end{array}$ & $\begin{array}{c}\text { No. of samples } \\
\text { under standard } \\
\text { permissible limit } \\
(\%)\end{array}$ & $\begin{array}{c}\text { No. of samples } \\
\text { over standard } \\
\text { permissible limit } \\
(\%)\end{array}$ & Undesired effect \\
\hline pH (Fig.2) & 8.5 & 94 & 6 & Taste \\
\hline EC (Fig. 3) & $1400(\mathrm{dS} / \mathrm{m})$ & 91 & 9 & Gastrointestinal irritation \\
\hline TDS (Fig. 4) & $1000(\mathrm{mg} / \mathrm{l})$ & 94 & 6 & Gastrointestinal irritation \\
\hline $\mathrm{Cl}^{-}$(Fig. 5) & $250(\mathrm{mg} / \mathrm{l})$ & 76 & 24 & Salty taste \\
\hline $\mathrm{CO}_{3}{ }^{2-}$ (Fig. 6) & $120(\mathrm{mg} / \mathrm{l})$ & \multicolumn{2}{|c|}{ Not present } & - \\
\hline $\mathrm{HCO}_{3}^{-}$(Fig. 7) & $1000(\mathrm{mg} / \mathrm{l})$ & 100 & - & - \\
\hline $\mathrm{Ca}^{2+}$ (Fig. 8) & $75(\mathrm{mg} / \mathrm{l})$ & 81 & 19 & Scale formation \\
\hline $\mathrm{Mg}^{2+}$ (Fig. 9) & $55(\mathrm{mg} / \mathrm{l})$ & 91 & 9 & - \\
\hline $\mathrm{Na}^{+}$(Fig. 10) & $200(\mathrm{mg} / \mathrm{l})$ & 83 & 17 & High blood pressure \\
\hline $\mathrm{K}^{+}$(Fig. 11) & $55(\mathrm{mg} / \mathrm{l})$ & 90 & 10 & Bitter taste \\
\hline $\mathrm{B}^{3 \pm}$ (Fig. 12) & $2.5(\mathrm{mg} / \mathrm{l})$ & 100 & 0 & Affect internal organs \\
\hline $\mathrm{SO}_{4}{ }^{2-}$ (Fig. 13) & $400(\mathrm{mg} / \mathrm{l})$ & 100 & 0 & Laxative effect \\
\hline
\end{tabular}


Table.4 Calculation for proportionality constant $(\mathrm{K})$ and unit weight $(\mathrm{Wn})$ for groundwater quality parameters using the standard permissible limits for the study area

\begin{tabular}{|c|c|c|c|}
\hline \multirow[t]{2}{*}{ Parameter } & $\begin{array}{l}\text { Standard permissible limit of a } \\
\text { parameter for drinking (WHO, } \\
2006)\end{array}$ & $\begin{array}{l}\text { Inverse of standard } \\
\text { Permissible limit }\end{array}$ & Unit Weight \\
\hline & $\left(V_{\mathrm{s}}\right)$ & $\left(1 / \mathrm{V}_{\mathrm{s}}\right)$ & $\left(\mathrm{Wn}=\mathrm{K} / \mathrm{V}_{\mathrm{s}}\right)$ \\
\hline $\mathbf{p H}$ & 8.5 & 0.1176 & 0.1994 \\
\hline EC & $1400(\mathrm{dS} / \mathrm{m})$ & 0.0007 & 0.0012 \\
\hline TDS & $1000(\mathrm{mg} / \mathrm{l})$ & 0.0010 & 0.0017 \\
\hline $\mathrm{Cl}^{-}$ & $250(\mathrm{mg} / \mathrm{l})$ & 0.0040 & 0.0068 \\
\hline $\mathrm{CO}_{3}{ }^{2-}$ & $120(\mathrm{mg} / \mathrm{l})$ & 0.0083 & 0.0141 \\
\hline $\mathrm{HCO}_{3}{ }^{-}$ & $1000(\mathrm{mg} / \mathrm{l})$ & 0.0010 & 0.0017 \\
\hline $\mathrm{Ca}^{2+}$ & $75(\mathrm{mg} / \mathrm{l})$ & 0.0133 & 0.0226 \\
\hline $\mathrm{Mg}^{2+}$ & $55(\mathrm{mg} / \mathrm{l})$ & 0.0182 & 0.0308 \\
\hline $\mathrm{Na}^{+}$ & $200(\mathrm{mg} / \mathrm{l})$ & 0.0050 & 0.0085 \\
\hline $\mathbf{K}^{+}$ & $55(\mathrm{mg} / \mathrm{l})$ & 0.0182 & 0.0308 \\
\hline $\mathbf{B}^{3 \pm}$ & $2.5(\mathrm{mg} / \mathrm{l})$ & 0.4000 & 0.6780 \\
\hline \multirow[t]{2}{*}{$\mathrm{SO}_{4}{ }^{2-}$} & $400(\mathrm{mg} / \mathrm{l})$ & 0.0025 & 0.0042 \\
\hline & $\Sigma V n=0.5899$ & $K=\Sigma V n=1.695$ & $\Sigma W n=1$ \\
\hline
\end{tabular}

Fig.1 Location map of study area
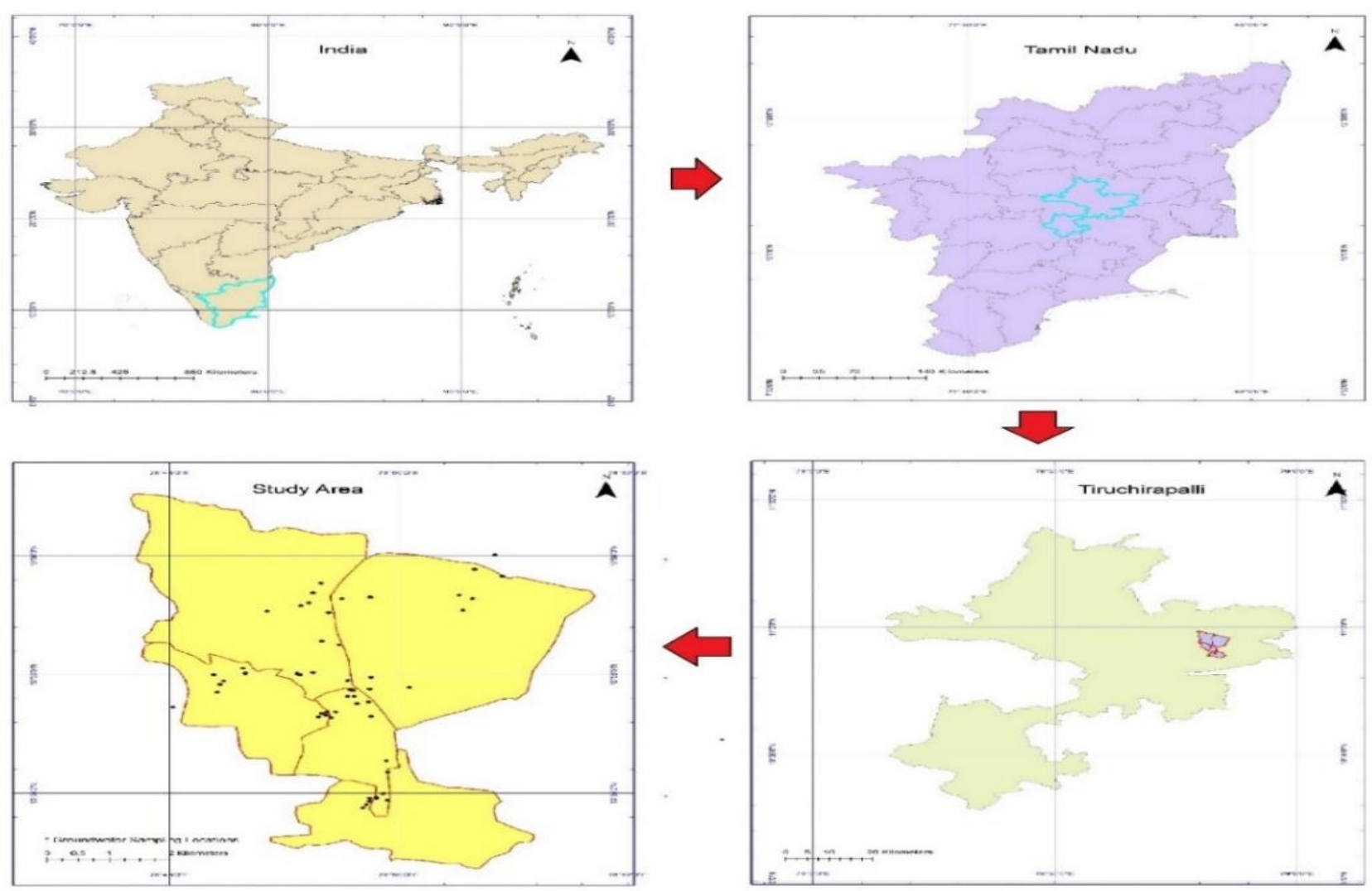


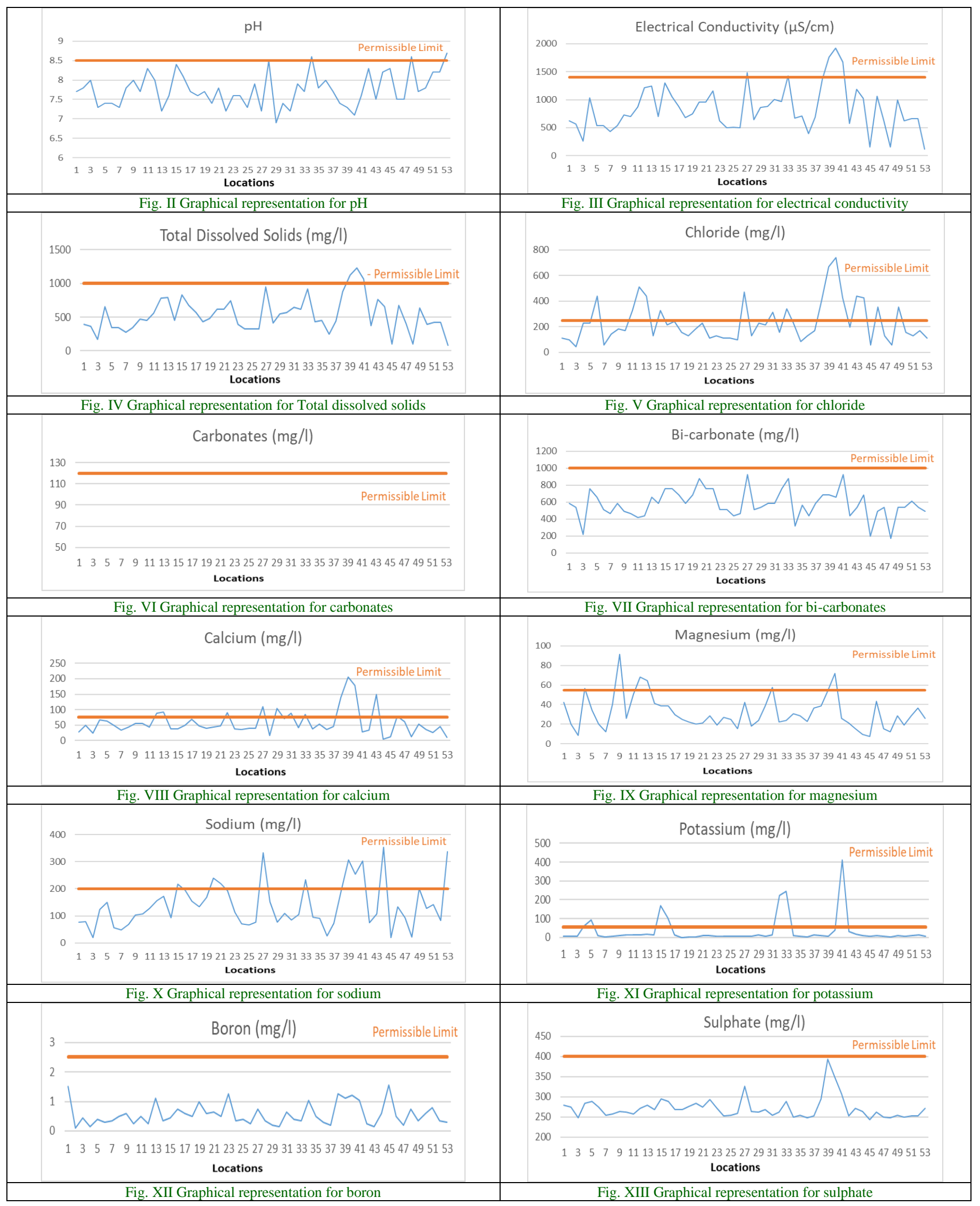




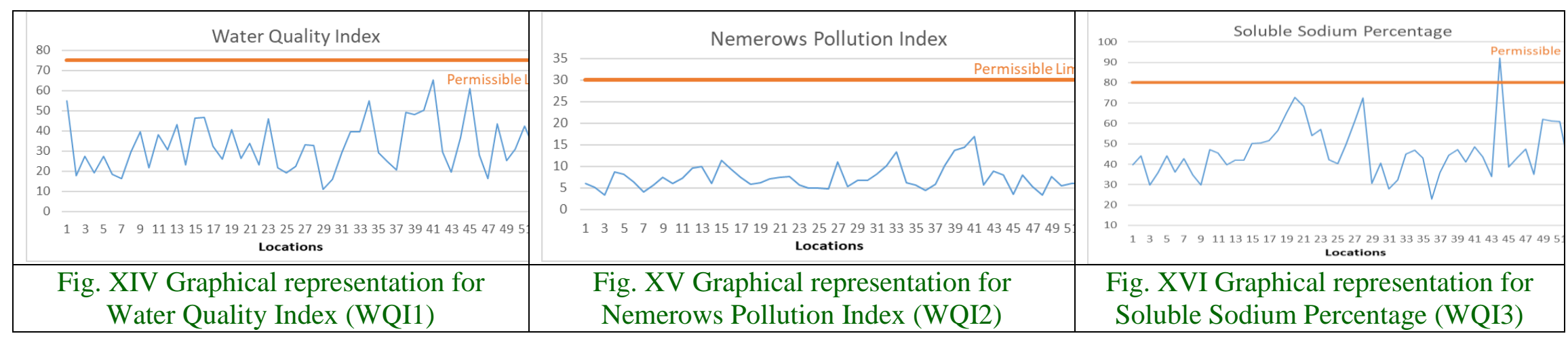



Fig. XVII Variability in study area for groundwater based on Water Quality Index

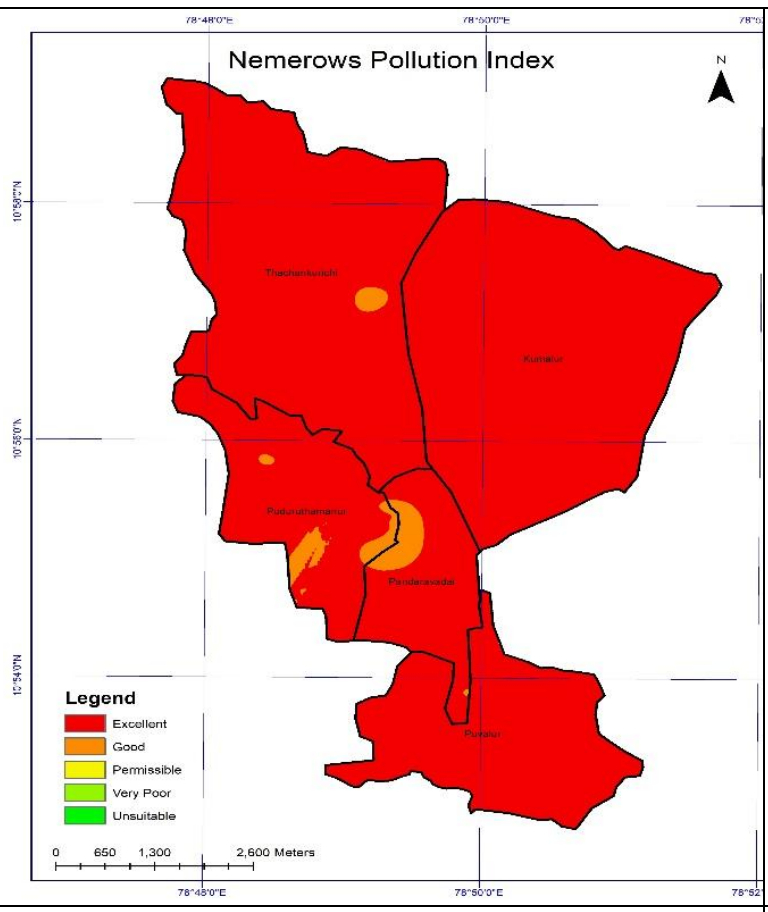

Fig. XVIII Variability in study area for groundwater based on Nemerows Pollution Index

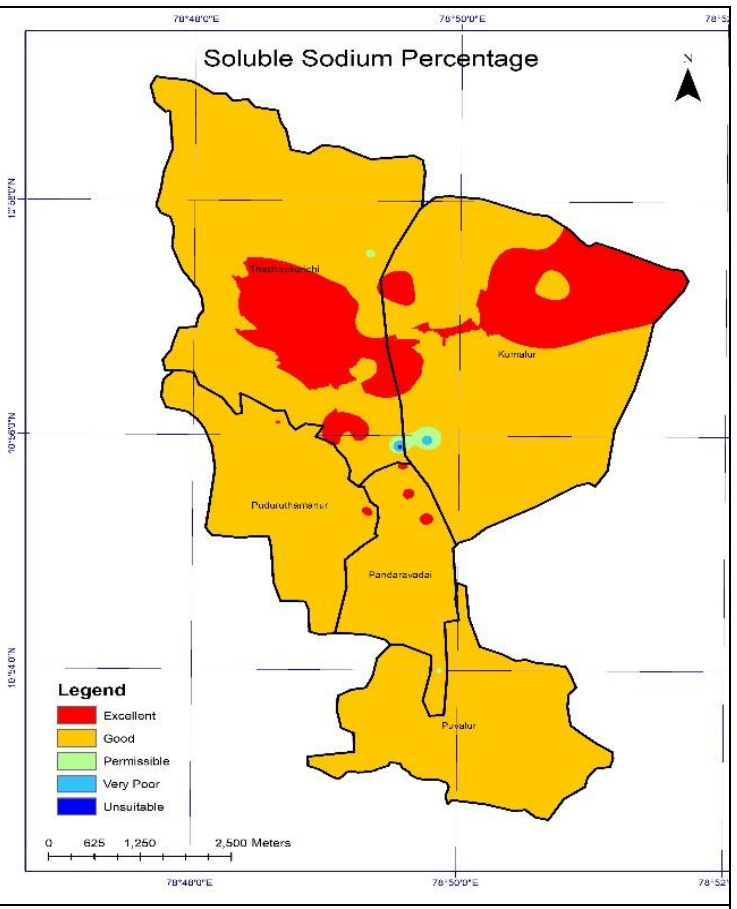

Fig. XIX Variability in study area for groundwater based on Soluble Sodium Percentage 


\section{Soluble sodium percentage}

Soluble sodium percentage needs an expression of parameters in milli-equivalence per litre (me/l). Hence the concentration in milligram per litre ( $\mathrm{mg} / \mathrm{l}$ or $\mathrm{ppm})$ was divided with the atomic weight of the element. Further, the WQI3 was estimated using the above methodology and the WQI3 was obtained. Classification of WQI was bone base on the ratings given in Table 2 .

The above classification shows $4 \%$ samples comes under poor and unsuitable water quality, $62 \%$ samples good water quality and $30 \%$ samples comes under excellent water quality for irrigation. The interpolation map for WQI3 was obtained as shown in Fig. XIX. The higher values of WQI means the water needs to be treated prior to using for drinking or irrigation purposes.

In conclusion, one or more than one parameter can contribute towards higher values of water quality index (WQI1, WQI2 and WQI3). Comparing WQI1, WQI2 and WQI3, it was concluded that, by WQI1 and WQI2, the water sample from the entire study area is suitable for drinking purpose. Since many physico-chemical properties of the samples are below the permissible limits, WQI value is also lower which leads to the suitability of water for drinking purpose. It also concludes the suitability of water for drinking. In WQI3, $44.66 \mathrm{~km}^{2}$ area is within the permissible limits and $0.44 \mathrm{~km}^{2}$ area lied under very poor or unsuitable water quality ratings which indicated the need for treatment, prior to use for irrigation purposes (Rawat and Singh, 2018).

Groundwater is a natural resource, meeting demands of a large population in the arid and semi-arid regions. Evaluation of groundwater is important to understand the physicochemical properties for the management of the resource. The study also shows the effectiveness of using WQIs and GIS for groundwater quality assessment. WQI involves categorization of water-based on multiple parameters, resulting in a composite unit for determining the quality of water with one value. GIS helps in interpretation of point data into special data, thereby categorizing the area under good and poor water quality. Thus further different algorithms could be developed, driven by water quality index for assessment of groundwater quality in GIS environment.

\section{References}

APHA. (1998). Standard method for the examination of water and wastewater (20th ed.). Washington, DC: American Public Health Association.

Mani. A.K., Santhi. R., Sellamuttu. K.M., (2007). A Handbook of Laboratory Analysis. A.E. Publication, Coimbatore, pp. 184-199.

Nemerow, Nelson Leonard, 1971, "Benefits of water quality enhancement", Environmental Protection Agency, Water Quality Office, for sale by the Supt. of Docs., US Govt. Print. Off.

Rawat K. S. and Singh Sudhir Kumar (2018). "Water Quality Indices and GIS based evaluation of a decadal groundwater quality", Geology, Ecology, and Landscapes, 2:4, 240-255.

Reddy, S.K (2013) Assessment of groundwater quality for irrigation of Bhaskar Rao Kunta watershed, Nalgonda District, India, Vol 5(7), pp. 418-425, July 2013.

Suresh, S. (2008). District Groundwater brochure Tiruchirappalli District, Tamil Nadu.Central Ground Water Board South Eastern Coastal Region Chennai.

Sureshkumar M., Sivakumar R., Nagarajan M.,(2016)." Impact of Municipal Solid Waste Dump Yard on Ground Water - 
A Case Study of Kanchipuram Municipality, Tamil Nadu, India", International Journal of Chem Tech Research CODEN, Vol.9, No.09 pp 571-579.

Talukder MSU, Shirazi SM, Paul UK (1998). Suitability of Groundwater for Irrigation at Kirimganj Upazila Kishoreganj. Progress Agric. 9:107-112.

Vaidheki, M. and Arulanandu, U. 2017. Estimating Extreme Temperature at Agricultural Engineering College and Research Institute, Kumulur Station by Using Generalized Extreme Value Distribution. Int.J.Curr.Microbiol.App. Sci. 6(11): 3874-3886.

Vasanthavigar, M., Srinivasamoorthy, K.,
Vijayaragavan, K., R. Rajiv Ganthi· S. Chidambaram.P. Anandhan $\cdot R$. Manivannan.S. Vasudevan. (2010). Application of water quality index for groundwater quality assessment: Thirumanimuttar sub-basin, Tamilnadu, India. Environ Monit Assess 171, 595609.

Wilcox LV (1955). Classification and Use of Irrigation Water, Washington: US Department of Agriculture. Circular No. 969, p. 19.

World Health Organization. (2006). Guidelines for drinking water quality. Recommendations (Vol 1, 3rd ed.). Geneva: World Health Organization.

\section{How to cite this article:}

Arvind Gauns, M. Nagarajan, R. Lalitha and Baskar, M. 2020. GIS-based Assessment of Groundwater Quality for Drinking and Irrigation by Water Quality Index. Int.J.Curr.Microbiol.App.Sci. 9(03): 2361-2370. doi: https://doi.org/10.20546/ijcmas.2020.903.269 